\title{
ENVIRONMENTAL, SOCIAL, AND GOVERNANCE (ESG) PRACTICE AND FIRM PERFORMANCE: AN INTERNATIONAL EVIDENCE
}

\author{
Imlak SHAIKH① \\ Management Development Institute Gurgaon, Gurugram, Haryana, India
}

Received 12 January 2021; accepted 11 October 2021

\begin{abstract}
This article attempts to bring quantitative evidence of a firm's sustainability reporting in terms of non-financial voluntary disclosures. The disclosures are made available through the annual report and Corporate Social Responsibility (CSR) and Global Reporting Initiatives (GRI) report. ESG score is a quantitative measure developed and disseminated by Bloomberg, covering about 120 Environmental, Social, and Governance aspects. The study's research problem is to examine the effects of non-market transnational sustainability strategy on firm performance. The study presents an analysis of nearly 510 firm's ESG scores across 17 countries for 2010-2018. The descriptive and inductive statistical analysis shows that ESG compliance is more pronounced in European companies. Simultaneously, Asian firms are more disciplined concerning the energy sector, and the Asiapacific counterpart is more inclined toward technology firms. The study shows that GRI and nonGRI companies differ significantly in their accounting performance (ROA and ROE) and market valuations (Tobin's-Q). The environmental dimension appears intimidating across accounting and market-based firm performance, while the social dimension contributes adversely, and governance positively affects operational efficiency.
\end{abstract}

Keywords: environmental, social, governance, ESG score, sustainability, firm performance.

JEL Classification: G30, G32, M41, Q51, Q56.

\section{Introduction}

Environmental, Social, and Governance (ESG) reporting has gained more popularity among organizations and socially responsible communities. Stakeholders and fund managers believe that firms with high ESG disclosures yield better operating performance, higher returns, and lower firm-specific risk. In this article, an attempt has been made to bring some novel quantitative evidence of a firm's sustainability reporting in the form of non-financial voluntary disclosures. The quantitative and qualitative disclosures are made available through the annual and Corporate Social Responsibility (CSR) and Global Reporting Initiatives (GRI) reports.

${ }^{\star}$ Corresponding author. E-mail: imlak.shaikh@mdi.ac.in

Copyright (c) 2022 The Author(s). Published by Vilnius Gediminas Technical University

This is an Open Access article distributed under the terms of the Creative Commons Attribution License (http://creativecommons. org/licenses/by/4.0/), which permits unrestricted use, distribution, and reproduction in any medium, provided the original author and source are credited. 
ESG score is a quantitative measure developed and disseminated by Bloomberg, covering about 120 Environmental, Social, and Governance aspects. The literature and empirical studies on the relationship between sustainability disclosure (SD) and financial performance (FP) have grown exponentially in the last three decades. But still, abundant inconclusive evidence attracts sustainability scholars to fill this void concerning SD and FP. The empirical attempt is novel in two terms: First, the study considers the large sample across the industries and firms belonging to seventeen emerging and developed nations. Second, an analysis has been presented based on the GRI compliance and CSR sustainability committee.

The Financial Times Lexicon expresses ESG as "a generic term used in capital markets and used by investors to evaluate corporate behaviour and to determine the future financial performance of companies". The analyst and investor frequently consult the ESG scores to evaluate the financial performance of the firms. ESG is the non-financial score that tracks the company's sustainability practice in terms of environment, social, and governance reporting. ESG score is calculated annually using quantitative and policy-related data from the company's annual reports and CSR documents and scaled from 0 to 100. Syed (2017) deliberates on the managerial decision-making mechanism by surveying fund managers considering ESG related information in the UK and France. Authors find that environmental and social responsibility remains the main concern for the French firms while regulating the UK. Further, Broadstock et al. (2020) examine CSR choices, ESG implementation strategies, and the firm's innovation capacity, with the convention ESG policies directly impacting operational efficiency and market value. A study of around 320 Japanese firms for 2008-2016 shows that ESG policies allow firms to engage in innovative activities that turn into better value creation and financial performance. The research problem is to examine the effects of nonmarket transnational sustainability strategy on the firm's operational efficiency, profitability, and market consideration. Hence, the study aims to present essential quantitative evidence of a firm's sustainability reporting regarding non-financial voluntary disclosures, e.g., corporate social responsibility and/or global reporting initiatives. Research questions are twofold: (i) Does ESG compliance affect firm performance? (ii) Does Sustainability practice contribute positively to the firm value and profitability?

The study of ESG practice and firm's performance proceeds as Section "Introduction" presents the study's introduction and motivation. Section 1 presents literature evidence. Section 2 describes a method, data sources, and preliminary analysis. Section 3 and 4 summarizes the results and robustness check. Section 5 offers a discussion, and the last section elucidates the conclusion.

\section{Literature and theoretical framework and hypotheses development}

Schueth (2003) claims that the economic-behavior and rational-choice theory transact with the individual's self-interest in utility maximization and psychological assessment of people's behavior in the decision-making process (Syed, 2017; Broadstock et al., 2020). When looking way back to hundred years - CSR activity and ESG policies hold a very long history. Stakeholder engagement is subject to people's belief in business's ethical nature, type of Industry, concern for the environment, and social and governance issues (Renneboog et al., 2007; 
Waring \& Lewer, 2004). US SIF foundation (2020) surveys about 530 institutional investors holding a substantial investment in ESG assets - a report highlights that fund managers raise their apprehensions about climate change and carbon emissions, affecting around \$2.6 trillion assets class. Also, a report reveals some crucial insights on the investor's advocacy articulated in terms of political activity and corporate lobbying.

Some recent studies (e.g., Khan, 2019; Fiskerstrand et al., 2020; Stotz, 2021; Torre et al., 2020) deal with ESG compliance and governance, ESG ratings, and financial performance, ESG preferences or commitment, and expected returns. Besides, some notable works (e.g., Chen \& Yang, 2020; Consolandi et al., 2020; Cornell, 2021; Maiti, 2020) examine the information contained in the ESG disclosures and ESG materiality and momentum effects on the equity premiums and ESG risk factor in returns forecasting. Hence, unlike the previous studies, the study presents international evidence on the sustainability practice and the firm's financial performance. In order to deliberate on the relation between SD and FP, the study offers literature and empirical evidence in the following sections.

\subsection{Sustainability disclosure and practice}

Escrig-Olmedo et al. (2010) explain the importance of socially responsible financial markets among the investing community. The authors review the sustainability indexes and sustainability information providers based on six sustainability indexes and ten ESG agencies. The authors conclude that there is a lot of stringency and a lack of standardization for sustainability indices. Likewise, Crews (2010) presents a systematic review of sustainability implementation and describes leadership challenges. The author brings the grounded theory framework, meta-analysis and questionnaire, and in-depth interviews for the sustainability implementation. Also, Pérez-Calderón et al. (2011) studied 122 European firms part of the Dow Jones Sustainability Index Europe. They found that firms with the best environmental practices have yielded better stakeholders' economic and financial benefits. Besides, Searcy and Elkhawas (2012) performed a content analysis of 24 Canadian firms about sustainability implementation with DJSI North America's logo. They find that firms adopt a wide range of sustainability strategies for inclusion in the DJSI index. Further improving the DJSI index, authors suggest streamlining the questionnaire, coordinating rating agencies, and enhancing transparency. Also, Lee and Saen (2012) explain corporate sustainability management using data envelopment analysis (DEA) and provide various suggestions to build an optimal corporate sustainability strategy.

Cohen et al. (2012) study the disclosure of non-financial information on the economic performance and sustainability for the 50 public companies in the US during 2004. The authors report a lack of proper standardization of those indicators in terms of the firm's size and Industry class and argue that such disclosures can benefit if a third party attests. Further, Galbreath (2013) analyses Australian Securities Exchange (ASX) listed 300 firms in respect of ESG disclosure, taking the time frame of 2002-09 with the support of institutional theory prediction and discover that high impact firms outperformed over low impact in terms of sustainability practice. Moreover, Orsato et al. (2015) recently reviewed sustainability indexes and conducted some interviews with the corporate leaders about joining the sustainability 
indexes (e.g., ISE, Brazil). Their survey supports the institutional theory and reveals that voluntary reporting of non-financial information creates new capabilities, reputational gain, better communication of knowledge; firms with all these characteristics are considered ESG compliant and sustainability practice firms. More interestingly, Morioka and de Carvalho (2016) present a systematic review of sustainability performance over an extended study of published literature and propose mainly three critical considerations in sustainability performance collective values, processes and practices, and internal and external aspects of substantivity. Besides, Hummel and Schlick (2016) study the relationship between sustainability performance and sustainability disclosure and report that high-quality sustainability disclosure led to superior sustainability performance, reflecting sustainability performance to the market and capital market participation.

\subsection{Sustainability practice and firm performance}

There have been many studies that document the relationship between sustainability practice and financial performance. Walley and Whitehead (1994) and Hamilton (1995) report that sustainability practice increased operational expenditures and Capex. Scholars Porter (1991) and Flammer (2015) find that sustainability disclosures benefit all stakeholders and eventually achieve encouraging accounting profitability. However, few studies, for example, Hamilton (1995), Khanna and Damon (1999), and Konar and Cohen (2001), show an adverse impact of sustainability practice on financial performance. Hence, the abovementioned early studies report asymmetric evidence on the effects of the sustainability practice, which allows us to perform a further statistical investigation on the relationship between sustainability and firm performance. Next paragraph, we present some of the recent studies that analyze the SP and FP.

Velte (2017) examines companies listed on the German stock exchange considering ESG performance and financial performance for 2010-2014 and found a positive impact on accounting performance but no impact on the market value (Tobin's Q). Moreover, Li et al. (2018) examine FTSE listed 350 firms in relation to ESG disclosure and firm value. The authors find that ESG disclosure enhances stakeholder trust improves a firm's value. And further, they report CEO power to contribute positivity to the ESG practice. More recently, Yoon et al. (2018) analyse the ESG score to evaluate Korean firms' CSR performance and found that environmentally sensitive Industries contribute less to CSR performance. CSR practice shows a favorable impact on the firm's market value.

Fatemi et al. (2018) investigate the relation between ESG performance and firm value for the US firms for the period 2006-2011 in relation to the ESG strengths and weaknesses and report an asymmetric effect on the financial performance. The authors say ESG strengths enhance the firm value while ESG concerns decline. Most importantly, the authors find that governance-induced disclosure shows a more substantial impact than environmental and social concerns. Atan et al. (2018) studies the ESG issues and financial performance of Malaysian public limited companies and found a weak association between sustainability reporting and profitability and firm value but a positive link with the firm's cost of capital. Unlike the previous studies, Aouadi and Marsat (2018) examine the ESG related controversies and 
firm value with the data of more than 4000 companies across 58 nations for the timeline 2002-2011. The authors find that ESG controversies contribute positively to the firm value. Still, when ESG and Corporate Social Performance (CSR) are taken together, it shows an adverse association, essential insights from the findings are that firms can increase their visibility through CSP and materialize it in high valuation and better profitability.

Minutolo et al. (2019) explore the ESG scores of the S\&P 500 firms for the period 20092015 based on the stakeholder and legitimacy theory. The authors report that an enhanced level of transparency increases the firm value and improves operational efficiency. Further, ESG performance substantially affects the large firms concerning Tobin's-Q and ROA and is weak for the smallest firms. Likewise, Duque-Grisales and Aguilera-Caracuel (2021) examine the impact of ESG performance for Latin American companies, e.g., Brazil, Chile, Colombia, Mexico, and Peru, with 104 firms for the period 2011-2015. The authors report a significant negative association between ESG and firm performance and find that this relation holds due to the moderating effects of the financial slack and international geographical diversification. Further, a recent quantitative review of Huang (2021) on the link between ESG performance and Corporate Financial Performance weight of the empirical evidence reports a positive association and finds ESG activity is dubious about being primarily driven by narrow measures of financial performance. Hence, a null on the relationship between the various dimension of sustainability and firm performance is as

Hypothesis $H_{1}$ : ESG compliance (i.e., ENV, SOC, and GOV) and firm performance is positively connected

Recent studies, e.g., Cek and Eyupoglu (2020), examine the S\&P 500 firms using ESG disclosures for the timeline 2010-2015 and show that overall ESG practice brings a significant impact on economic performance. Ting et al. (2020) explore the effects of ESG practice in the developed and emerging market firms and find that emerging market had high ESG scores and firms with ESG controversies affect adversely market valuation, and governance remain the leading sustainability indicator for the firm valuation.

There have been many studies (e.g., Crews, 2010; Searcy \& Elkhawas, 2012; and Orsato et al., 2015; Fatemi et al., 2018; Minutolo et al., 2019; Huang, 2021 and Al Hawaj \& Buallay, 2022) speaks about sustainability implementations, corporate sustainability practice, trends in the sustainability reporting, GRI reporting, and strategies for sustainability deployment. But still, many divergences and corroborative evidence motivate to analyze the Sustainability Disclosure (SD) and Financial Performance (FP). The study fills this gap by referring to the global dataset on sustainability reporting and firm performance. Hence, the literature presented above clearly explains that sustainability disclosures are essential in getting attention from the investing community and providing a competitive advantage to be included in the sustainability indexes. Studies show that sustainability led to more stakeholder engagement, social responsibility, enhanced corporate social responsibility, and more transparency and high market valuation. The work also expresses the hypotheses considering GRI compliance and constitution of the CSR committee and its impact on the firm performance

Hypothesis $\mathrm{H}_{2}$ : Sustainability practice and firm performance is positively connected 
Luo and Bhattacharya (2006) and Hussain et al. (2018) argues that GRI-based governance reporting yields better profitability and enhanced market valuation. Moreover, recent studies Wang et al. (2014) and Fatemi et al. (2018) show that GRI compliance and CSR sustainability appear to be unpretentious with the accounting and market-based performance. Hence, the following hypothesis is set

Hypothesis $\mathrm{H}_{3}$ : GRI-compliant firms appear with high ESG scores and are positively linked with financial performance.

\section{Method and data description and descriptive analysis}

\subsection{Methodology}

The study expresses empirical specification in a panel data set on the relationship between a firm's financial performance and ESG compliance. On the left-hand side, the firm's performance indicators are considered and calculated in terms of Returns on Assets (ROA), Returns on Equity (ROE), and Tobin's-Q. On the right-hand side, work also encompasses various sustainability parameters (ESG) along with control variables.

$$
F P_{i t}=\delta_{1}+\sum_{i=2}^{k} \delta_{j} X_{j i t}+\sum_{l=1}^{m} \lambda_{l} Z_{l i t}+u_{i t} .
$$

Variable description: $F P_{i t}$ - A dependent variable denotes the firm's performance, considered either ROA, ROE, and Tobin's Q; $\delta_{1}$ - Intercept coefficient, most of the studies report +ve intercept, hence in the stated model it should assume positive sign; $X_{j i t}-$ Vector of Sustainability and ESG parameter, e.g., ESG - score - Overall or combined sustainability disclosure score (+/-); ENV - score - Environmental disclosure score (+/-); SOC - score Social disclosure score (+/-); GOV - score - Governance disclosure score (+/-); GRI - A variable denotes firms following Global Reporting Initiatives, Dummy variable: If YES = 1 Otherwise =0; (+/-); CSRSUST - A variable indicates CSR Sustainability Committee, Dummy variable: If YES $=1$ Otherwise $=0 ;(+/-) ; Z_{l i t}-$ Vector of a firm's control variables, e.g., SALGWT - Percentage of Sales Growth (+); CR - Current Ratio (+/-); DTE - Debt to equity ratio (+/-); Size - Total Assets, a log-transformed value considered (-); CAP_INT - Capex intensity measured as the ratio of capital expenditure to total assets (-); RD_INT - Research and development intensity measured as the ratio of development expenditure to total assets $(-)$.

The model considers various vectors of sustainability and ESG indicators that act as independent variables explaining the firm performance (e.g., Jaggi \& Freedman, 1992; Judge \& Douglas, 1998; Siregar \& Bachtiar, 2010; Gallego-Álvarez et al., 2014; Hussain et al., 2018; Ting et al., 2020). Considering the $\mathrm{H}_{1}$ slope associated with ESG parameters should appear positive and statistically significant. Moreover, evaluating $\mathrm{H}_{2}$ and $\mathrm{H}_{3}$, the coefficient linked to GRI and CSRSUST should be estimated positive and significant (e.g., Wagner, 2010; Gregory et al., 2016; Wiengarten et al., 2017). Further, the slope coefficient associated with a firm's control variables should be calculated as reported in the literature. 


\subsection{Data description and preliminary analysis}

The study in relation to a firm's financial performance (FP) and ESG compliance considers the world's top companies with the highest market cap on their respective stock exchanges. In the case of more than 30 stocks listed on the benchmark stock indexes, the top 30 companies have been chosen based on their highest market cap (see Appendix). Data annual fiscal has been collected from Bloomberg from the period 2010-2018. There are 17 countries in the sample from which 30 firms have been chosen, resulting in 4500 longitudinal data points; after applying the required filter and outlier removal effectively, there are 3690 observations. The work accounts for various ESG parameters and other variables concerning the firm's performance and is controlled with other indicators.

Table 1. Descriptive statistics - ESG reporting and score (source: author's calculation)

\begin{tabular}{|l|l|c|c|c|c|}
\hline \multicolumn{2}{|c|}{ COUNTRY/Equity Index } & Mean & Max. & Min. & Obs. \\
\hline Australia & S\&P/ASX 200 & 35.43 & 63.90 & 9.92 & 256 \\
\hline Brazil & IBOVESPA & 47.45 & 73.14 & 6.61 & 268 \\
\hline Canada & S\&P/TSX & 25.06 & 58.09 & 9.09 & 233 \\
\hline China & SSE & 29.34 & 55.79 & 10.33 & 270 \\
\hline Europe & STOXX50 & 54.70 & 75.09 & 34.30 & 267 \\
\hline France & CAC40 & 52.43 & 69.01 & 22.73 & 265 \\
\hline Germany & DAX & 47.05 & 72.31 & 3.31 & 250 \\
\hline India & NIFTY50 & 31.88 & 58.68 & 9.65 & 249 \\
\hline Indonesia & IDX Composite & 24.04 & 52.48 & 6.14 & 160 \\
\hline Italy & FTSE MIB & 42.69 & 78.07 & 3.51 & 255 \\
\hline Japan & Nikkei 225 & 41.11 & 62.81 & 7.85 & 264 \\
\hline Mexico & IPC & 33.31 & 73.55 & 5.37 & 221 \\
\hline South Africa & ZAR & 38.80 & 59.92 & 10.53 & 156 \\
\hline South Korea & KOSPI & 40.92 & 66.23 & 10.74 & 260 \\
\hline Taiwan & TAIEX & 41.89 & 82.02 & 10.33 & 270 \\
\hline UK & FTSE & 47.57 & 68.46 & 15.70 & 267 \\
\hline USA & DJIA & 42.82 & 74.79 & 14.05 & 249 \\
\hline
\end{tabular}

Table 1 summarizes the descriptive statistics of ESG scores across countries. We are now looking at the mean level of scores European firms notch on average high 54.70 while other Indonesian companies score on average low 24.04. Globally one can see the mean ESG measured 39.79, which is quite far away from the maximum level of 100. The top ESG level was found to be for Taiwan (82.02); a further second maximum measurement appears for Indonesia (52.48) (e.g., Ting et al., 2020). Lastly, the minimum level of ESG reading appears for the European and German firms. Figure 1 exhibits ESG scores across countries categorized as ENV-score, SOC-score, and GOV-score. One can see that Governance disclosure scores appear on the higher side and are further followed by Social and Environment practice. In terms of corporate governance, the UK and USA firms score 


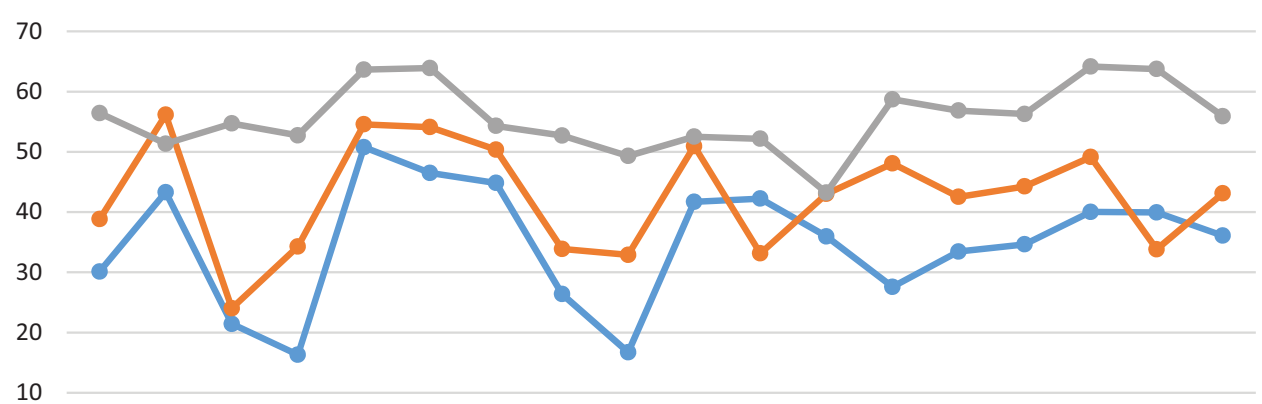

0

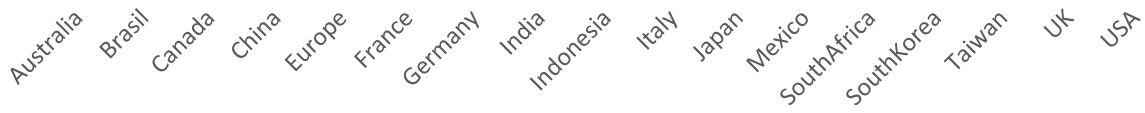

$$
\multimap \text { ENV } \multimap \text { SOC } \multimap \text { GOV }
$$

Figure 1. ESG scores country wise (source: author's calculation)

\section{ESG-Score}

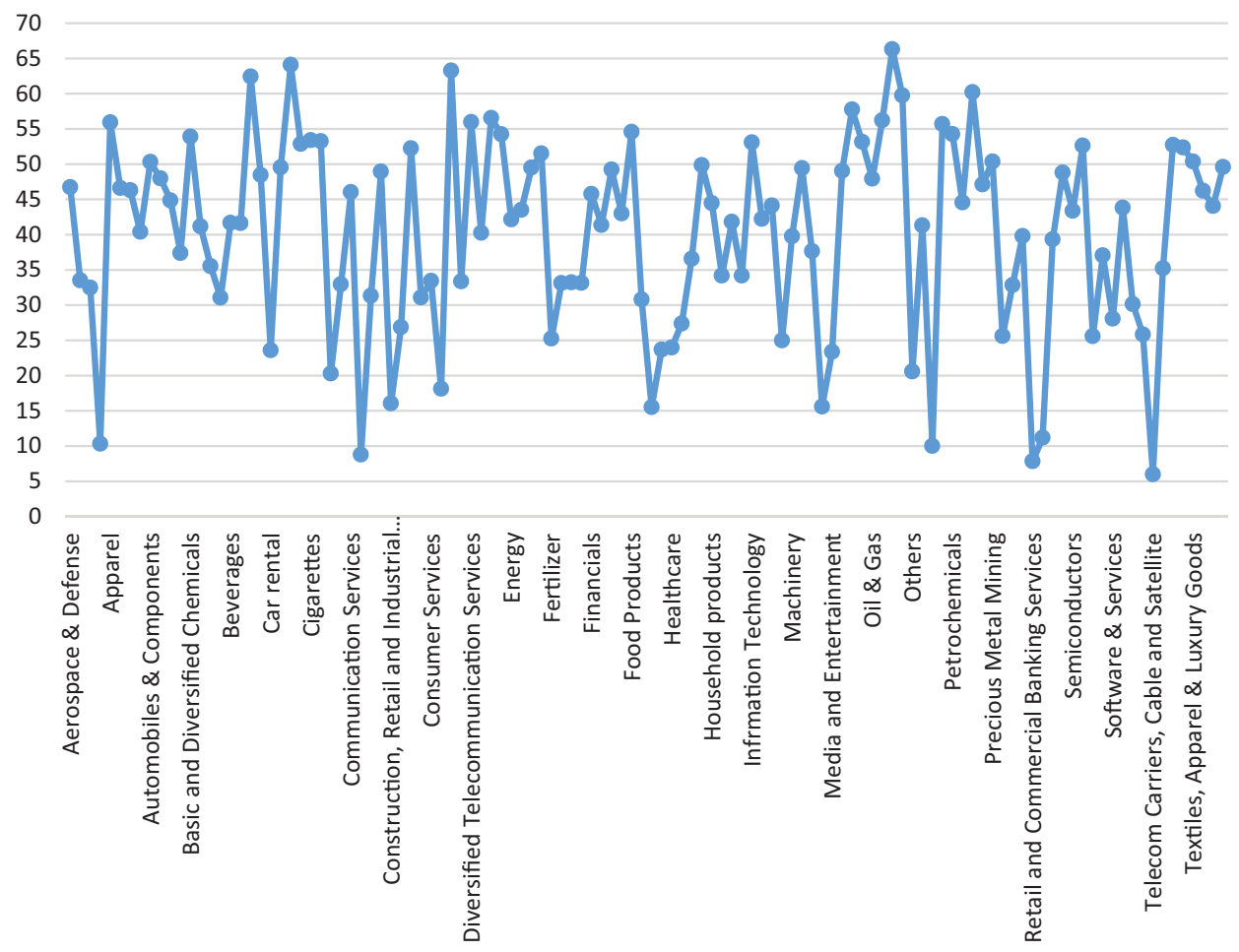

Figure 2. Industry-wise ESG score (source: author's calculation) 
highest (64.16 and 63.75). However, firms from Brazil score highest (56.16) concerning the social and human aspects of sustainability practice, and it's low for Canadian firms (24.03). Again, European, German, and France companies were found to be more environmentally conscious higher in the disclosure scores. At the same time, China and Indonesian firms are very low in sustainability practice's environmental aspect. Figure 2 shows the visual displays of ESG scores across the Industry. One can see that Oil and Gas and Cement, and Aggregates firms are more active in terms of environmental, social, and governance disclosures, and the same is relatively low for the Beverages, Infrastructure project, Telco, Cable, and Satellite companies.

Further, analysis has been presented using Kruskal-Wallis KW-stat, which follows the chi-squares distribution. The firms that follow the GRI framework for sustainability disclosure are designated with indicator variable 1 , otherwise 0 . The second indicator variable is CSRSUST: CSR sustainability committee firms who constituted this committee assigned 1 otherwise 0 . It's prominent that companies following the GRI and CSRSUST committee will score higher ESG scores. Hence, the hypothesis is "Firms are more transparent in sustainability practice following GRI and CSRSUST".

Non-parametric tests evidenced that the firms' median score following the sustainability standards scores higher ESG in total and individually as well. The median score of the environmental, social, and governance parameters appears to be higher for those firms which are GRI and CSR compliant. The KW-stat across all sustainability indicators seems to be statistically significant, which signifies that median disclosure of sustainability practice varies significantly companywide when proper sustainability guidelines are absent. Further, statistical evidence is presented on sustainability practice and financial performance. The statistical hypothesis is that "sustainable firms report better operating performance and regard high value in public". It is clearly apparent that GRI and non-GRI companies differ significantly in their accounting performance (ROA and ROE) and market valuations (Tobin's-Q). It is also evident that their median score performance metrics are lower for the firms GRI-compliant (e.g., Hamilton, 1995; Khanna \& Damon, 1999; Konar \& Cohen, 2001).

On the other hand, CSR practices do not significantly differ in terms of financial performance (e.g., Pava \& Krausz, 1996; King \& Lenox, 2001 and Link \& Naveh, 2006). Two hypotheses are set based on the stakeholder theory perspective, which is partially true in terms of sustainability practice (e.g., Hussain et al., 2018) and quite corroborative concerning financial performance. This result is further tested in the next section based on the empirical model ${ }^{1}$.

Table 2 reports spearman's correlation coefficient between financial and non-financial performance metrics. First, we look at the ESG disclosures and financial performance; it seems that all sustainability disclosures indicators and accounting and market-based firm performance are adversely associated. The degree of negative association appears to be higher $(-0.190)$ for the environmental disclosures and return of assets. Similarly, it is inadequately correlated with the return on equity and Tobin's-Q $(-0.164)$. The social and governance compliances also depict adverse associations with financial performance. The

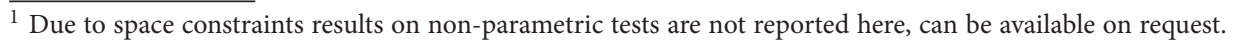




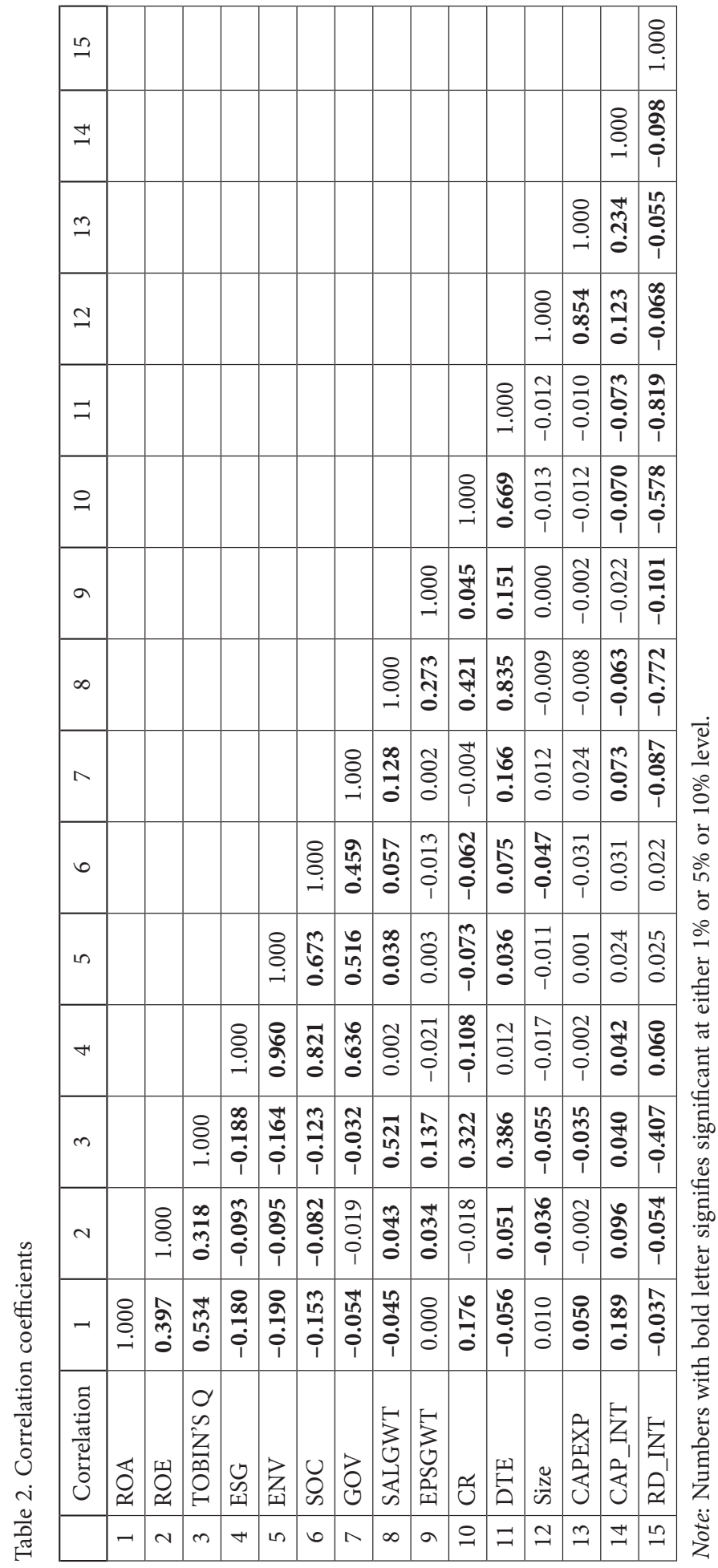


results support the view of Walley and Whitehead (1994) and Hamilton (1995) that sustainability practice results in a substantial rise in operational overhead. Likewise, authors Khanna and Damon (1999), Konar and Cohen (2001), Surroca and Tribó (2008), and Orens and Cormier (2010) establishes a negative correlation between sustainability practice and financial performance and market value. But one can see that sales growth and environmental, social, and governance disclosure shows a positive association, scholars, for example, Hart and Ahuja (1996), Judge and Douglas (1998), Goll and Rasheed (2004), Prado-Lorenzo et al. (2008) report encouraging relation between sustainability practice and sales growth. Second, the Capex-intensity and R\&D-intensity were positive concerning overall ESG compliance.

\section{Results}

Table 3 reports the estimation result for the Eq. (1). ESG is the aggregate score of environmental, social, and governance disclosure practices measured between 0 and 100. It seems that the slope of the ESG appears to be negative across all financial performance indicators and statistically significant at a $1 \%$ level. The adverse estimate signifies that sustainability implementation results in decreased ROA and ROE and further lowers the firm's market valuation. Considering the effects of the control variable on the performance - Capex intensity shows a positive impact, while R\&D intensity appears to be significantly positive for Tobin's-Q. The firm's size shows an adverse effect, while sales growth positively contributes to return on assets and market value. The firm's leverage was recorded with a significant negative impact while sustainable firm's liquidity encouraged relation with ROA and Tobin's-Q.

Table 3. Regression results for the combined ESG score and financial performance

\begin{tabular}{|c|c|c|c|c|c|c|}
\hline \multirow{2}{*}{ Regressors } & \multicolumn{2}{|c|}{$R O A$} & \multicolumn{2}{|c|}{$R O E$} & \multicolumn{2}{|c|}{ Tobin's-Q } \\
\hline & Estimate & $t-s t a t$ & Estimate & $t-s t a t$ & Estimate & $t-s t a t$ \\
\hline Intercept & 10.0152 & $6.44^{\mathrm{a}}$ & 72.1841 & $10.12^{\mathrm{a}}$ & 4.3829 & $12.10^{\mathrm{a}}$ \\
\hline$E S G$ & -0.0499 & $-5.58^{a}$ & -0.2483 & $-6.06^{\mathrm{a}}$ & -0.0187 & $-8.92^{\mathrm{a}}$ \\
\hline CAPEX_INT & 26.9903 & $8.31^{\mathrm{a}}$ & 68.0432 & $4.56^{\mathrm{a}}$ & 3.3896 & $4.47^{\mathrm{a}}$ \\
\hline$R \& D \_I N T$ & 0.2072 & 0.33 & -0.8171 & -0.28 & 0.3474 & $2.36^{b}$ \\
\hline Size & -0.4013 & $-5.48^{\mathrm{a}}$ & -1.8366 & $-5.46^{\mathrm{a}}$ & -0.1437 & $-8.42^{\mathrm{a}}$ \\
\hline DTE & -0.0002 & $-10.54^{\mathrm{a}}$ & 0.0004 & $3.69^{\mathrm{a}}$ & -0.0005 & $-9.43^{\mathrm{a}}$ \\
\hline SALGWT & 0.0012 & $4.86^{\mathrm{a}}$ & -0.0025 & $-2.26^{b}$ & 0.0013 & $23.77^{a}$ \\
\hline$C R$ & 1.8133 & $14.83^{\mathrm{a}}$ & -3.2861 & $-5.86^{a}$ & 0.3022 & $10.61^{\mathrm{a}}$ \\
\hline Number & \multicolumn{2}{|c|}{3243} & \multicolumn{2}{|c|}{3237} & \multicolumn{2}{|c|}{3231} \\
\hline$R$ - squared & \multicolumn{2}{|c|}{0.16} & \multicolumn{2}{|c|}{0.09} & \multicolumn{2}{|c|}{0.35} \\
\hline Firm FE & \multicolumn{2}{|c|}{ YES } & \multicolumn{2}{|c|}{ YES } & \multicolumn{2}{|c|}{$Y E S$} \\
\hline Time FE & \multicolumn{2}{|c|}{ YES } & \multicolumn{2}{|c|}{ YES } & \multicolumn{2}{|c|}{ YES } \\
\hline
\end{tabular}

Note: Table shows the regression output for the Eq. (1), showing the link between ESG practice and firms' financial performance. Robust standard errors for the test's statistics. Significant at ${ }^{\mathrm{a}} 1 \%,{ }^{\mathrm{b}} 5 \%$, ${ }^{c} 10 \%$ level. 
Table 4 shows an extended version estimation for the Eq. (1) concerning mainly three sub-dimensions of ESG disclosure. First, one can see that the environmental dimension coefficient, which appears negative across accounting and market-based firm performance. The respective estimates are $-0.027(\mathrm{t}$-stat $=-2.66),-0.058(\mathrm{t}$-stat $=-1.19)$ and $-0.0074(\mathrm{t}$ stat $=-3.13)$. Second, the social dimension of sustainability also contributes adversely and appears significant for the profitability $(-0.19$, t-stat $=-3.98)$ and market value $(-0.0038$, $\mathrm{t}$-stat $=-1.70)$ at $1 \%$ and $10 \%$ levels. Third, the governance dimension is positively associated with operating efficiency and market value (e.g., Ting et al., 2020). One can see that the slope of the governance indicator in an association of return on assets was found to be 0.040 with a significant $t$-stat $=2.47$ at a $5 \%$ level. Hence, at this point, one can say that sustainability practice (SP) and financial performance (FP) are significantly associated. To achieve and deploy sustainability standards (e.g., GRI standards) requires more Capex and R\&D. One can see that, along with sustainability dimensions, Capex intensity and R\&D intensity show a significant association with the firm's performance. But only Capex intensity shows positive effects while research and development show weak relations. Again, the firm's size was found to be adversely related to all three FP measures. The sales growth and liquidity show a positive impact, while leverage contributes adversely to ROA and Tobin's-Q.

Table 4. Regression results for the sub-dimension of ESG score and financial performance

\begin{tabular}{|c|c|c|c|c|c|c|}
\hline \multirow{2}{*}{ Regressors } & \multicolumn{2}{|c|}{$R O A$} & \multicolumn{2}{|c|}{$R O E$} & \multicolumn{2}{|c|}{ Tobin's-Q } \\
\hline & Estimate & $t-s t a t$ & Estimate & $t-s t a t$ & Estimate & $t-s t a t$ \\
\hline Intercept & 8.7025 & $4.99^{\mathrm{a}}$ & 71.8191 & $8.57^{\mathrm{a}}$ & 3.9452 & $10.12^{a}$ \\
\hline$E N V$ & -0.0271 & $-2.66^{\mathrm{a}}$ & -0.0583 & -1.19 & -0.0071 & $-3.13^{\mathrm{a}}$ \\
\hline SOC & -0.0140 & -1.40 & -0.1922 & $-3.98^{a}$ & -0.0038 & $-1.70^{c}$ \\
\hline GOV & 0.0400 & $2.47^{\mathrm{a}}$ & 0.1191 & 1.53 & 0.0009 & 0.26 \\
\hline CAPEX_INT & 26.3685 & $8.13^{\mathrm{a}}$ & 76.0378 & $4.88^{\mathrm{a}}$ & 3.0168 & $4.16^{\mathrm{a}}$ \\
\hline$R \& D \_I N T$ & -0.0423 & -0.07 & 0.0938 & 0.03 & 0.0936 & 0.67 \\
\hline Size & -0.4775 & $-6.39^{a}$ & -2.1688 & $-6.03^{a}$ & -0.1410 & $-8.44^{\mathrm{a}}$ \\
\hline$D T E$ & -0.0003 & $-11.58^{\mathrm{a}}$ & 0.0004 & $3.54^{\mathrm{a}}$ & -0.0001 & $-12.10^{a}$ \\
\hline$S A L G W T$ & 0.0012 & $5.35^{\mathrm{a}}$ & -0.0022 & $-1.95^{c}$ & 0.0014 & $26.29^{a}$ \\
\hline$C R$ & 1.8905 & $15.31^{\mathrm{a}}$ & -3.1378 & $-5.29^{a}$ & 0.3521 & $12.75^{\mathrm{a}}$ \\
\hline Number & \multicolumn{2}{|c|}{3026} & \multicolumn{2}{|c|}{3021} & \multicolumn{2}{|c|}{3019} \\
\hline$R$ - squared & \multicolumn{2}{|c|}{0.18} & \multicolumn{2}{|c|}{0.09} & \multicolumn{2}{|c|}{0.40} \\
\hline Firm FE & \multicolumn{2}{|c|}{ YES } & \multicolumn{2}{|c|}{ YES } & \multicolumn{2}{|c|}{ YES } \\
\hline Time FE & \multicolumn{2}{|c|}{$Y E S$} & \multicolumn{2}{|c|}{$Y E S$} & \multicolumn{2}{|c|}{$Y E S$} \\
\hline
\end{tabular}

Note: Table shows the regression output for the Eq. (1), showing the link between the sub-dimension of ESG practice and firms' financial performance. Robust standard errors for the test's statistics. Significant at ${ }^{\mathrm{a}} 1 \%,{ }^{\mathrm{b}} 5 \%$, ${ }^{\mathrm{c}} 10 \%$ level. 
Table 5. Regression results for the sub-dimension of ESG score and financial performance mediated with GRI and CSR sustainability

\begin{tabular}{|c|c|c|c|c|c|c|}
\hline \multirow{2}{*}{ Regressors } & \multicolumn{2}{|c|}{$R O A$} & \multicolumn{2}{|c|}{$R O E$} & \multicolumn{2}{|c|}{ Tobin's-Q } \\
\hline & Estimate & $t-s t a t$ & Estimate & $t-s t a t$ & Estimate & $t-s t a t$ \\
\hline Intercept & 8.0180 & $4.50^{\mathrm{a}}$ & 62.7105 & $7.43^{a}$ & 3.7991 & $9.43^{a}$ \\
\hline$E N V$ & -0.0224 & $-2.13^{b}$ & -0.0464 & -0.93 & -0.0067 & $-2.81^{\mathrm{a}}$ \\
\hline SOC & -0.0122 & -1.19 & -0.1570 & $-3.24^{\mathrm{a}}$ & -0.0031 & -1.36 \\
\hline GOV & 0.0566 & $3.22^{\mathrm{a}}$ & 0.2842 & $3.42^{\mathrm{a}}$ & 0.0037 & 0.92 \\
\hline GRI & -0.5844 & $-1.67^{c}$ & -3.6887 & $-2.22^{b}$ & -0.1405 & $-1.77^{c}$ \\
\hline CSRSUST & -0.3220 & -1.15 & -3.5622 & $-2.69^{a}$ & 0.0179 & 0.28 \\
\hline CAPEX_INT & 24.5508 & $7.52^{a}$ & 69.0869 & $4.47^{\mathrm{a}}$ & 2.8714 & $3.89^{\mathrm{a}}$ \\
\hline$R \& D \_I N T$ & -0.0456 & -0.07 & 0.1935 & 0.07 & 0.0946 & 0.67 \\
\hline Size & -0.4587 & $-6.10^{a}$ & -1.9851 & $-5.57^{a}$ & -0.1371 & $-8.06^{\mathrm{a}}$ \\
\hline DTE & -0.0003 & $-11.44^{\mathrm{a}}$ & 0.0004 & $3.38^{\mathrm{a}}$ & -0.0001 & $-12.00^{\mathrm{a}}$ \\
\hline SALGWT & 0.0012 & $5.27^{\mathrm{a}}$ & -0.0021 & $-1.96^{b}$ & 0.0014 & $26.11^{\mathrm{a}}$ \\
\hline$C R$ & 1.8295 & $14.79^{\mathrm{a}}$ & -3.3445 & $-5.71^{a}$ & 0.3480 & $12.44^{\mathrm{a}}$ \\
\hline Number & \multicolumn{2}{|c|}{2971} & \multicolumn{2}{|c|}{2966} & \multicolumn{2}{|c|}{2965} \\
\hline$R$ - squared & \multicolumn{2}{|c|}{0.18} & \multicolumn{2}{|c|}{0.10} & \multicolumn{2}{|c|}{0.41} \\
\hline Firm FE & \multicolumn{2}{|c|}{ YES } & \multicolumn{2}{|c|}{ YES } & \multicolumn{2}{|c|}{ YES } \\
\hline Time FE & \multicolumn{2}{|c|}{ YES } & \multicolumn{2}{|c|}{ YES } & \multicolumn{2}{|c|}{ YES } \\
\hline
\end{tabular}

Note: Table shows the regression output for the Eq. (1), showing the link between sub-dimension of ESG practice and firms' financial performance mediated with GRI and CSR sustainability, GRI and SCRSUST are the indicator variables that assume 1 for sustainability practice otherwise 0 . Robust standard errors for the test's statistics. Significant at ${ }^{\mathrm{a}} 1 \%,{ }^{\mathrm{b}} 5 \%,{ }^{\mathrm{c}} 10 \%$ level.

Table 5 describes the result by including two more sustainability practice indicators expressed in terms of the dummy variable. GRI is the dummy variable that assumes one for the companies following and implementing the GRI standards (e.g., GRI citing, G1.0, G2.0, G3.0, G3.1, and G4), otherwise zero. CSRSUST is the dummy variable that assumes one for the firm's CSR committee practicing sustainability activities, otherwise zero. It is seen that the respective estimates of GRI $(\mathrm{ROA}=-.0 .58, \mathrm{t}$-stat $=-1.67$; $\mathrm{ROE}=-3.69$, $\mathrm{t}$-stat $=-2.22$; $\mathrm{TQ}=-0.14$, t-stat $=-1.77)$ calculated negative and statistically significant. For example, Hussain et al. (2018) report a negative association between sub-dimension (Economicaspect_EC_GRI3.0) sustainability and financial performance, while in other aspects (e.g., Environmental and Social), it shows positive results. Let measure CSR sustainability's effects on the market value, which appears positive while it brings a lower return on equity. Further, environmental and social disclosures on firm performance appear adversely, but governance positively impacts profitability and market value. Other control variables show similar results reported in the previous paragraphs. 


\section{Robustness check}

\subsection{GRI Compliance and ESG disclosures}

This section deliberates on the statistical evidence and their robustness, experimenting with alternative regression specifications, and considering other proxies for the financial performance. The regression model has been expressed with GRI, as an interaction term,

$$
F P_{i t}=\delta_{1}+\sum_{j=2}^{k} \delta_{j} X_{j i t} G R I_{j i t}+\sum_{l=1}^{m} \lambda_{l} Z_{l i t}+u_{i t}^{\prime},
$$

where $X_{j i t} G R I_{j i t}$ - is the interaction term in relation to ESG parameters and GRI compliance. The interaction dummy indicator measures the magnitude of GRI compliance among the firms depicted in terms of enhanced disclosures on the environment, social, and governance issues. GRI is the dummy variable that assumes one for the GRI compliance, otherwise zero. The empirical hypothesis H3: GRI compliant firms appear with high ESG scores and are positively linked with financial performance.

The Eq. (2) has been expressed as an interaction dummy variable based on GRI compliance and all three sustainability practice dimensions. Again, the results are in line with the previous outcomes and literature evidence. The environmental and social disclosures score with GRI compliance brings an adverse impact on the firm's performance. The GRI-based governance reporting yields better profitability and enhanced market valuation (e.g., Luo \& Bhattacharya, 2006; Hussain et al., 2018). Importantly one can see that GRI compliance and CSR sustainability appear to be downbeat with the accounting-based performance and market-based performance (e.g., Wagner et al., 2002; Brammer et al., 2006; Surroca \& Tribo, 2008; Wang et al., 2014; Fatemi et al., 2018). The Capex intensity seems to be encouraging for all performance indicators, but R\&D explains the firm's market value positively. Further, sales growth contributes positively to the return on assets and Tobin's- $\mathrm{Q}$ but adversely with the return on equity ${ }^{2}$.

\subsection{ESG and financial performance (networth and net profit margin)}

In order to check the robustness of regression results of the Eq. (1) the study considers = either Return on Networth (RONWT) or Net Profit Margin (NETPRFT). ESG disclosure shows an adverse effect on the returns on the networth and profitability but is not significant (e.g., Jaggi \& Freedman, 1992). One of the essential findings reported here is that GRIcompliance shows a considerable positive contribution to stakeholder's wealth creation and net earnings (e.g., Judge \& Douglas, 1998). But CSR practice depicts a weak association with networth and net profitability. The R\&D intensity causes negatively to the networth but encouraging impact on the net profit margin. Further, sales growth and leverage contribute positivity to both financial performance metrics ${ }^{2}$.

\footnotetext{
${ }^{2}$ Due to space constraints results on robustness check are not reported here, can be available on request.
} 


\section{Discussion and its implications}

One of the interesting observations based on the institutional theory is that only European firms are more concerned about voluntary environmental, social, and governance disclosures. It also implies that in the sustainability practice (SP), the firm's governance remains the main concern for voluntary disclosures second consideration is social responsibility. Looking through the lens of stakeholder and legitimacy theory - Socially responsible companies nowadays voluntarily practicing GRI standards and constituting a CSR sustainability committee to address various environmental, social, and governance issues. GRI is the global sustainability practice standard issued by a global reporting organization headquartered in Amsterdam, Netherlands. GRI standards are formulated based on stakeholder's perspectives and public interest, more statistical evidence and discussion on GRI compliance are presented in the next section. It enables companies to communicate critical sustainability issues such as environment, human rights, social wellbeing, and governance. The statistical evidence shows that environmental disclosure and return on assets are adversely associated while it's weak in terms of market-linked performance Tobin's-Q. Further, social and governance compliances also depict adverse associations with financial performance.

It's evident that when companies decide to practice sustainability need to employ more financial resources in terms of non-monetary assets, which results in an increased amount of Capex considerable amount of operational overhead. During the initial fiscal years of sustainability practice, the undertaking's profitability shrinks due to increased overheads. Hence, one can see that ESG shows an adverse impact on the accounting-based performance metrics and similar market-linked performance effects. The empirical outcomes reported are consistent with the studies of Makni et al. (2009) and Hussain et al. (2018) based on the stakeholder theory; hence study's notion is against hypotheses $\mathrm{H}_{1}$ and $\mathrm{H}_{2}$. The environmental and social disclosures contribute adversely, while governance practice remains more encouraging for the firm performance. One of the essential findings apparent from the results is that Corporate Governance (CG) and enhanced transparency in the governance structure and board diversity matter for sustainability and contribute positively to the firm's operational efficiency and market valuation.

\section{Conclusions}

The study aimed to explain the relationship between sustainability disclosures (SD) and the firm's financial performance (FP). The empirical convention set for the work is that firms moving toward instantaneous sustainability disclosure, getting more attention and regards from the stakeholders, outperforming in the long run with improved profitability and market value. The study explains the importance of voluntary reporting of non-financial indicators and a firm's accountability toward stakeholders, reflecting the firm's financial performance. Researchers and analysts find ESG assessment more relevant due to stakeholder's growing interest in ESG firms and their financial performance. Hence, the firm's ESG focus and going net-zero are the companies' exceptional commitment through carbon reduction and further achieving the goal of the Paris agreement for sustainable development. 
The adverse estimate of the ESG signifies that sustainability implementation results in a decline of ROA and ROE and further lower market valuation of the firm. The Capex intensity shows a positive impact, while R\&D intensity appears to be significantly positive for Tobin'sQ. The firm's size shows an adverse effect, while sales growth positively contributes to return on assets and market value. The firms' leverage was recorded with significant adverse impact while sustainable firms' liquidity with an encouraging relation with ROA and Tobin's-Q. The environmental dimension appears negative across accounting and market-based firm performance. Also, the social dimension of sustainability contributes adversely. It seems significant for profitability. But the governance dimension depicts a positive association with the operating efficiency and the firm's market value. Thus, empirical results evidence that sustainability practice (SP) and financial performance (FP) are significantly associated.

Policy implication/practical recommendations: (i) Firms must ensure higher GRI compliance by introducing Industry-leading practices like independent committees (ii) In order to have a swift implementation of sustainability standards; firms can constitute sub-dimension committees broadly covering various aspects of Economic, Environmental, Labour, Human rights, Society and Product responsibility. (iii) The empirical outcome shows that a firm's performance responds positively to the governance aspects; hence board diversity, executive compensation, board meetings, and board independence should have enhanced the reporting. The study contributes to the relevant literature on sustainability practice and its relative advantages in risk management and strategy building. But the work is limited up to ESG disclosures and their determinants. Hence, the result can be further extended in terms of sustainability performance and indicators of sustainability practice.

\section{Acknowledgements}

The author wants to thank Founder and Deputy Editor-in-Chief Romualdas Ginevičius, and Managing editor Prof. Martinkute Kaulienè, Raimonda, for the prompt editorial proceeding and feedback. The author thanks the two anonymous referees for the helpful comments and suggestions that have improved the work.

\section{References}

Al Hawaj, A. Y., \& Buallay, A. M. (2022). A worldwide sectorial analysis of sustainability reporting and its impact on firm performance. Journal of Sustainable Finance \& Investment, 12(1), 62-68. https://doi.org/10.1080/20430795.2021.1903792

Aouadi, A., \& Marsat, S. (2018). Do ESG controversies matter for firm value? Evidence from international data. Journal of Business Ethics, 151(4), 1027-1047.

https://doi.org/10.1007/s10551-016-3213-8

Atan, R., Alam, M. M., Said, J., \& Zamri, M. (2018). The impacts of environmental, social, and governance factors on firm performance. Management of Environmental Quality: An International Journal, 29(2), 182-194. https://doi.org/10.1108/MEQ-03-2017-0033

Brammer, S., Brooks, C., \& Pavelin, S. (2006). Corporate social performance and stock returns: UK evidence from disaggregate measures. Financial Management, 35(3), 97-116.

https://doi.org/10.1111/j.1755-053X.2006.tb00149.x 
Broadstock, D. C., Matousek, R., Meyer, M., \& Tzeremes, N. G. (2020). Does corporate social responsibility impact firms innovation capacity? The indirect link between environmental \& social governance implementation and innovation performance. Journal of Business Research, 119, 99-110. https://doi.org/10.1016/j.jbusres.2019.07.014

Cek, K., \& Eyupoglu, S. (2020). Does environmental, social and governance performance influence economic performance? Journal of Business Economics and Management, 21(4), 1165-1184. https://doi.org/10.3846/jbem.2020.12725

Chen, H.-Y., \& Yang, S. S. (2020). Do Investors exaggerate corporate ESG information? Evidence of the ESG momentum effect in the Taiwanese market. Pacific-Basin Finance Journal, 63, 101407. https://doi.org/10.1016/j.pacfin.2020.101407

Cohen, J. R., Holder-Webb, L. L., Nath, L., \& Wood, D. (2012). Corporate reporting of non-financial leading indicators of economic performance and sustainability. Accounting Horizons, 26(1), 65-90. https://doi.org/10.2308/acch-50073

Consolandi, C., Eccles, R. G., \& Gabbi., G. (2020). How material is a material issue? Stock returns and the financial relevance and financial intensity of ESG materiality. Journal of Sustainable Finance \& Investment, 1-24. https://doi.org/10.1080/20430795.2020.1824889

Cornell, B. (2021). ESG preferences, risk and return. European Financial Management, 27(1), 12-19. https://doi.org/10.1111/eufm.12295

Crews, D. E. (2010). Strategies for implementing sustainability: Five leadership challenges. SAM Advanced Management Journal, 75(2), 15-21.

Duque-Grisales, E., \& Aguilera-Caracuel, J. (2021). Environmental, social and governance (ESG) scores and financial performance of multilatinas: Moderating effects of geographic international diversification and financial slack. Journal of Business Ethics, 168, 315-334.

https://doi.org/10.1007/s10551-019-04177-w

Escrig-Olmedo, E., Muñoz-Torres, M. J., \& Fernandez-Izquierdo, M. A. (2010). Socially responsible investing: Sustainability indices, ESG rating and information provider agencies. International Journal of Sustainable Economy, 2(4), 442-461.

Fatemi, A., Glaum, M., \& Kaiser, S. (2018). ESG performance and firm value: The moderating role of disclosure. Global Finance Journal, 38, 45-64. https://doi.org/10.1016/j.gf.2017.03.001

Fiskerstrand, S. R., Fjeldavli, S., Leirvik, T., Antoniuk, Y., \& Nenadić, O. (2020). Sustainable investments in the Norwegian stock market. Journal of Sustainable Finance \& Investment, 10(3), 294-310. https://doi.org/10.1080/20430795.2019.1677441

Flammer, C. (2015). Does corporate social responsibility lead to superior financial performance? A regression discontinuity approach. Management Science, 61(11), 2549-2568. https://doi.org/10.1287/mnsc.2014.2038

Galbreath, J. (2013). ESG in focus: The Australian evidence. Journal of Business Ethics, 118(3), 529-541. https://doi.org/10.1007/s10551-012-1607-9

Gallego-Álvarez, I., García-Sánchez, I. M., \& da Silva Vieira, C. (2014). Limate change and financial performance in times of crisis. Business Strategy and the Environment, 23(6), 361-374. https://doi. org/10.1002/bse.1786

Goll, I., \& Rasheed, A. A. (2004). The moderating effect of environmental munificence and dynamism on the relationship between discretionary social responsibility and firm performance. Journal of Business Ethics, 49(1), 41-54. https://doi.org/10.1023/B:BUSI.0000013862.14941.4e

Gregory, A., Whittaker, J., \& Yan, X. (2016). Corporate social performance, competitive advantage, earnings persistence and firm value. Journal of Business Finance \& Accounting, 43(1-2), 3-30. https://doi.org/10.1111/jbfa.12182

Hamilton, J. T. (1995). Pollution as news: Media and stock market reactions to the toxics release inventory data. Journal of Environmental Economics and Management, 28(1), 98-113.

https://doi.org/10.1006/jeem.1995.1007 
Hart, S. L., \& Ahuja, G. (1996). Does it pay to be green? An empirical examination of the relationship between emission reduction and firm performance. Business Strategy and the Environment, 5(1), 30-37. https://doi.org/10.1002/(SICI)1099-0836(199603)5:1<30::AID-BSE38>3.0.CO;2-Q

Huang, D. Z. (2021). Environmental, social and governance (ESG) activity and firm performance: A review and consolidation. Accounting \& Finance, 61(1), 335-360. https://doi.org/10.1111/acfi.12569

Hummel, K., \& Schlick, C. (2016). The relationship between sustainability performance and sustainability disclosure - Reconciling voluntary disclosure theory and legitimacy theory. Journal of Accounting and Public Policy, 35(5), 455-476. https://doi.org/10.1016/j.jaccpubpol.2016.06.001

Hussain, N., Rigoni, U., \& Cavezzali, E. (2018). Does it pay to be sustainable? Looking inside the black box of the relationship between sustainability performance and financial performance. Corporate Social Responsibility and Environmental Management, 25(6), 1198-1211. https://doi.org/10.1002/csr.1631

Jaggi, B., \& Freedman, M. (1992). An examination of the impact of pollution performance on economic and market performance: Pulp and paper firms. Journal of Business Finance \& Accounting, 19(5), 697-713. https://doi.org/10.1111/j.1468-5957.1992.tb00652.x

Judge, W. Q., \& Douglas, T. J. (1998). Performance implications of incorporating natural environmental issues into the strategic planning process: An empirical assessment. Journal of Management Studies, 35(2), 241-262. https://doi.org/10.1111/1467-6486.00092

Khan, M. (2019). Corporate governance, ESG, and stock returns around the world. Financial Analysts Journal, 75(4), 103-123. https://doi.org/10.1080/0015198X.2019.1654299

Khanna, M., \& Damon, L. A. (1999). EPA's voluntary 33/50 program: Impact on toxic releases and economic performance of firms. Journal of Environmental Economics and Management, 37(1), 1-25. https://doi.org/10.1006/jeem.1998.1057

King, A. A., \& Lenox, M. J. (2001). Does it really pay to be green? An empirical study of firm environmental and financial performance: An empirical study of firm environmental and financial performance. Journal of Industrial Ecology, 5(1), 105-116. https://doi.org/10.1162/108819801753358526

Konar, S., \& Cohen, M. A. (2001). Does the market value environmental performance? Review of Economics and Statistics, 83(2), 281-289. https://doi.org/10.1162/00346530151143815

Lee, K.-H., \& Saen, R. F. (2012). Measuring corporate sustainability management: A data envelopment analysis approach. International Journal of Production Economics, 140(1), 219-226. https://doi.org/10.1016/j.ijpe.2011.08.024

Li, Y., Gong, M., Zhang, X.-Y., \& Koh, L. (2018). The impact of environmental, social, and governance disclosure on firm value: The role of CEO power. The British Accounting Review, 50(1), 60-75. https://doi.org/10.1016/j.bar.2017.09.007

Link, S., \& Naveh, E. (2006). Standardization and discretion: Does the environmental standard ISO 14001 lead to performance benefits? EEE Transactions on Engineering Management, 53(4), 508-519. https://doi.org/10.1109/TEM.2006.883704

Luo, X., \& Bhattacharya, C. B. (2006). Corporate social responsibility, customer satisfaction, and market value. Journal of Marketing, 70(4), 1-18. https://doi.org/10.1509/jmkg.70.4.001

Maiti, M. (2020). Is ESG the succeeding risk factor? Journal of Sustainable Finance \& Investment, 1-15. https://doi.org/10.1080/20430795.2020.1723380

Makni, R., Francoeur, C., \& Bellavanc, F. (2009). Causality between corporate social performance and financial performance: Evidence from Canadian firms. Journal of Business Ethics, 89(3), 409. https://doi.org/10.1007/s10551-008-0007-7

Minutolo, M. C., Kristjanpoller, W. D., \& Stakeley, J. (2019). Exploring environmental, social, and governance disclosure effects on the S\&P 500 financial performance. Business Strategy and the Environment, 28(6), 1083-1095. https://doi.org/10.1002/bse.2303 
Morioka, S. N., \& Carvalho, M. M. (2016). A systematic literature review towards a conceptual framework for integrating sustainability performance into business. Journal of Cleaner Production, 136, 134-146. https://doi.org/10.1016/j.jclepro.2016.01.104

Orens, R. W., \& Cormier, D. (2010). Web-based non-financial disclosure and cost of finance. Journal of Business Finance \& Accounting, 37(9-10), 1057-1093.

https://doi.org/10.1111/j.1468-5957.2010.02212.x

Orsato, R. J., Garcia, A., Mendes-Da-Silva, W., Simonetti, R., \& Monzoni, M. (2015). Sustainability indexes: Why join in? A study of the "Corporate Sustainability Index (ISE)" in Brazil. Journal of Cleaner Production, 96, 161-170. https://doi.org/10.1016/j.jclepro.2014.10.071

Pava, M. L., \& Krausz, J. (1996). The association between corporate social-responsibility and financial performance: The paradox of social cost. Journal of Business Ethics, 15(3), 321-357. https://doi.org/10.1007/BF00382958

Pérez-Calderón, E., Milanés-Montero, P., Meseguer-Santamaría, M.-L., \& Mondéjar-Jiménez, J. (2011). Eco-efficiency: Effects on economic and financial performance. Evidences from Dow Jones sustainability Europe index. Environmental Engineering \& Management Journal, 10(12), 1801-1808. https://doi.org/10.30638/eemj.2011.243

Porter, M. E. (1991). America’s green strategy. Scientific American, 264(4), 168. https://doi.org/10.1038/scientificamerican0491-168

Prado-Lorenzo, J.-M., Gallego-Álvarez, I., García-Sánchez, I.-M., \& Rodríguez-Domínguez, L. (2008). Social responsibility in Spain: Practices and motivations in firms. Management Decision, 46(8), 1247-1271. https://doi.org/10.1108/00251740810901417

Renneboog, L., Simons, T., \& Wright, M. (2007). Why do public firms go private in the UK? The impact of private equity investors, incentive realignment and undervaluation. Journal of Corporate Finance, 13(4), 591-628. https://doi.org/10.1016/j.jcorpfin.2007.04.005

Searcy, C., \& Elkhawas, D. (2012). Corporate sustainability ratings: An investigation into how corporations use the Dow Jones Sustainability Index. Journal of Cleaner Production, 35, 79-92. https://doi.org/10.1016/j.jclepro.2012.05.022

Siregar, S. V., \& Bachtiar, Y. (2010). Corporate social reporting: Empirical evidence from Indonesia stock exchange. International Journal of Islamic and Middle Eastern Finance and Management, 3(3), 241-252. https://doi.org/10.1108/17538391011072435

Schueth, S. (2003). Socially responsible investing in the United States. Journal of Business Ethics, 43(3), 189-194. https://doi.org/10.1023/A:1022981828869

Stotz, O. (2021). Expected and realized returns on stocks with high-and low-ESG exposure. Journal of Asset Management, 22, 133-150. https://doi.org/10.1057/s41260-020-00203-z

Surroca, J., \& Tribó, J. A. (2008). Managerial entrenchment and corporate social performance. Journal of Business Finance \& Accounting, 35(5-6), 748-789. https://doi.org/10.1111/j.1468-5957.2008.02090.x

Syed, A. M. (2017). Environment, social, and governance (ESG) criteria and preference of managers. Cogent Business \& Management, 4(1), 1340820. https://doi.org/10.1080/23311975.2017.1340820

Ting, I. W., Azizan, N. A., Bhaskaran, R. K., \& Sukumaran, S. K. (2020). Corporate social performance and firm performance: Comparative study among developed and emerging market firms. Sustainability, 12(1), 26. https://doi.org/10.3390/su12010026

Torre, M. L., Mango, F., Cafaro, A., \& Leo, S. (2020). Does the ESG index affect stock return? Evidence from the Eurostoxx 50. Sustainability, 12(16), 6387. https://doi.org/10.3390/su12166387

US SIF. (2020). Report on US sustainable and impact investing trends 2020. https://www.ussif.org/files/ Trends\%20Report\%202020\%20Executive\%20Summary.pdf

Velte, P. (2017). Does ESG performance have an impact on financial performance? Evidence from Germany. Journal of Global Responsibility, 8(2), 169-178. https://doi.org/10.1108/JGR-11-2016-0029 
Wagner, M. (2010). The role of corporate sustainability performance for economic performance: A firm-level analysis of moderation effects. Ecological Economics, 59(7), 1553-1560. https://doi.org/10.1016/j.ecolecon.2010.02.017

Walley, N., \& Whitehead, B. (1994). It's not easy being green. In R. Welford \& R. Starkey (Eds.), The Earth scan reader in business and the environment' (pp. 36-44). Universities Press.

Wang, L., Li, S., \& Gao, S. (2014). Do greenhouse gas emissions affect financial performance? - an empirical examination of Australian public firms. Business Strategy and the Environment, 23(8), 505-519. https://doi.org/10.1002/bse.1790

Wagner, M., Van Phu, N., Azomahou, T., \& Wehrmeyer, W. (2002). The relationship between the environmental and economic performance of firms: An empirical analysis of the European paper industry. Corporate Social Responsibility and Environmental Management, 9(3), 133-146. https://doi.org/10.1002/csr.22

Waring, P., \& Lewer, J. (2004). The impact of socially responsible investment on human resource management: A conceptual framework. Journal of Business Ethics, 52(1), 99-108. https://doi.org/10.1023/B:BUSI.0000033110.21900.da

Wiengarten, F., Lo, C. K., \& Lam, J. Y. (2017). How does sustainability leadership affect firm performance? The choices associated with appointing a chief officer of corporate social responsibility. Journal of Business Ethics, 140(3), 477-493. https://doi.org/10.1007/s10551-015-2666-5

Yoon, B., Lee, J. H., \& Byun, R. (2018). Does ESG performance enhance firm value? Evidence from Korea. Sustainability, 10(10), 3635. https://doi.org/10.3390/su10103635

\section{APPENDIX}

\begin{tabular}{|c|c|c|}
\hline Countries & Benchmark Stock Index & \#companies \\
\hline Australia & S\&P/ASX 200 & 30 \\
\hline Brazil & IBOVESPA & 30 \\
\hline Canada & S\&P/TSX & 30 \\
\hline China & SSE & 30 \\
\hline Europe & STOXX50 & 30 \\
\hline France & CAC40 & 30 \\
\hline Germany & DAX & 30 \\
\hline India & NIFTY & 30 \\
\hline Indonesia & IDX Composite & 30 \\
\hline Italy & FTSE MIB & 30 \\
\hline Japan & Nikkei 225 & 30 \\
\hline Mexico & IPC & 30 \\
\hline South Africa & ZAR & 30 \\
\hline South Korea & KOSPI & 30 \\
\hline Taiwan & TAIEX & 30 \\
\hline UK & FTSE & 30 \\
\hline USA & DJIA & \\
\hline & & 30 \\
\hline & & \\
\hline
\end{tabular}

